\title{
Ni-Catalyzed Suzuki Arylation of Unactivated Tertiary Alkyl Halides
}

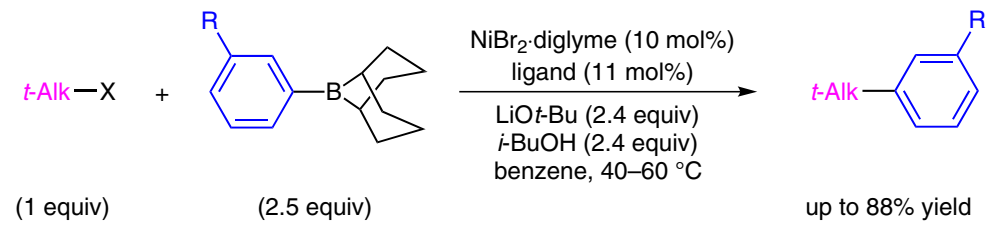

\section{Gategory \\ Metal-Mediated}

Synthesis

\section{Key words}

Suzuki crosscoupling

tertiary alkyl halides

nickel

\section{SYNFACTren}

t-Alk = unactivated tertiary alkyl $\mathrm{R}=\mathrm{H}, \mathrm{Me}, i-\mathrm{Pr}, \mathrm{Ph}$, OTBS, Oi-Pr $\mathrm{X}=\mathrm{Cl}, \mathrm{Br}, \mathrm{I}$

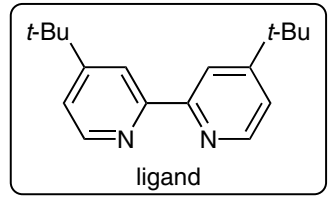

Selected examples:

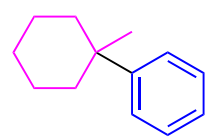

$84 \%$ yield<smiles>CC1(c2cccc([Se-])c2)CCCCC1</smiles>

$57 \%$ yield

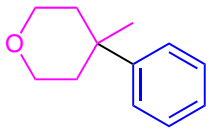

$57 \%$ yield<smiles>CCCc1cccc(C2(C)CCCCC2)c1</smiles>

$61 \%$ yield

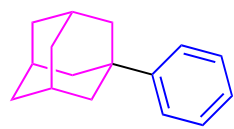

$74 \%$ yield<smiles>CC(C)(CCc1ccccc1)c1ccccc1</smiles>

$86 \%$ yield<smiles>CC1(c2cccc(-c3ccccc3)c2)CCCCC1</smiles>

$74 \%$ yield<smiles>O=Pc1ccccc1C1(PO)CCC1</smiles>

$53 \%$ yield<smiles>CC(C)=CCCC(C)(C)c1ccccc1</smiles>

$76 \%$ yield
Significance: The first nickel-catalyzed Suzuki cross-coupling reaction of unactivated tertiary alkyl halides has been disclosed. Both the nickel catalyst as well as the bipyridine ligand are commercially available. The desired products have been obtained in excellent yields.
Comment: The described reaction is very versatile since the synthesis of the all-carbon quaternary carbon centers does not suffer from isomerization of the alkyl group. Preliminary mechanistic studies indicate the generation of a radical intermediate along the reaction pathway. 